\title{
In times of change: How distance managers can ensure employees' wellbeing and
} organizational performance

\section{Poulsen, Signe; Ipsen, Christine}

\section{Published in:}

Safety Science

Link to article, DOI:

10.1016/j.ssci.2017.05.002

Publication date:

2017

Document Version

Peer reviewed version

Link back to DTU Orbit

Citation (APA):

Poulsen, S., \& Ipsen, C. (2017). In times of change: How distance managers can ensure employees' wellbeing and organizational performance. Safety Science, 100(Part A), 37-45. https://doi.org/10.1016/j.ssci.2017.05.002

\section{General rights}

Copyright and moral rights for the publications made accessible in the public portal are retained by the authors and/or other copyright owners and it is a condition of accessing publications that users recognise and abide by the legal requirements associated with these rights.

- Users may download and print one copy of any publication from the public portal for the purpose of private study or research.

- You may not further distribute the material or use it for any profit-making activity or commercial gain

- You may freely distribute the URL identifying the publication in the public portal

If you believe that this document breaches copyright please contact us providing details, and we will remove access to the work immediately and investigate your claim 
In times of change: How distance managers can ensure employees' wellbeing and organizational performance 


\begin{abstract}
Organizations develop and adapt to societal changes and technological developments, where one consequence is that dispersed workers are more common than never before. It is difficult to ensure employee wellbeing and performance, when separating managers from employees by either time or geography. This paper explores the wellbeing of employees doing distance work, and examines the practices of the distance manager aimed at ensuring employee wellbeing and organizational performance. The pilot study use a case study approach in four organizations with qualitative interviews of distance managers and employees. The study show both positive and negative aspects of distance work. Positively, the employees find distance work to be professionally challenging and they feel they make a difference in their work. On the negative side is the feeling of loneliness and frustrations about lack of communication. The analysis of distance managers' practices showed that they used both activities and capabilities in order to ensure employee wellbeing and organizational performance. The activities included planning, newsletters, and surveys, and the capabilities were to listen, create and show trust, and give authority to the employees. Contrary to previous findings on motivating of knowledge workers, our findings show that motivation, surprisingly, is ensured when focusing on the basic needs such as working conditions and belongingness.
\end{abstract}

Keywords: Distance management, case study, qualitative, knowledge work, virtual organizations 


\section{Introduction}

Over the years, workplaces and employees have become more dispersed due to organizational changes in large traditional organizations and the development of new business opportunities across the world, such as shifts from production to service- or knowledge- based work environment (Hinds and Kiesler, 2002). As companies move toward globalization and communication technologies facilitate a quicker pace of change within organizations (Bell and Kozlowski, 2002), companies use distance work (Fisher and Fisher, 2001 ) to accomplish work more effectively and efficiently. Distance work and management occur at different locations, such as from home (telework), in satellite offices (intraorganizational work), or at the customers' or clients' locations (inter-organizational work) (Cropper et al., 2008; Verburg et al., 2013).

Hertel et al. (2005) reported the potential disadvantages at the individual level when working across distances, including isolation, misunderstandings, decreased interpersonal contact, and role ambiguity (Hertel et al., 2005). In a systematic review, Crawford et al. (2011) found that only a few studies have investigated the wellbeing of employees who work at clients' or customers' offices (inter-organizational work) over a long period of time and how to best manage these employees. In inter-organizations, distance employees are employed by one company (the provider) but work at a different company (the customer) (Cropper et al., 2008; Hinds and Kiesler, 2002); here, the customer's working conditions influence the employees.

According to Westgaard and Winkel (2011), business rationalizations driven by increasing global competition and performance demands cause poor work environments and workrelated stress. However, most preventive intervention studies primarily consider employees' wellbeing, not the balance of both organizational performance and employees' wellbeing. Westgaard and Winkel (2011) call for studies of how work can be organized and managed to ensure both wellbeing and performance. Organizations that are able to combine the two are termed "sustainable production systems" (Westgaard and Winkel, 2011). In this paper the definition of wellbeing builds on a Danish interpretation including both the physical work environment and the psychosocial work environment (European Agency for Safety and Health at Work, 2013) and performance is defined as: to achieve the goals of the organization (Neely et al., 2005).

This paper explores how distance managers ensure both employees' wellbeing and organizational performance across distances (i.e., geography and time) (Fisher and Fisher, 2001) within the domain of inter-organizational distance work. To achieve this, the paper consists of two parts: First, it examines how distance employees (hereafter: employees) experience their work at the customer's site. Second, it investigates distance management practices and what employees expect from their managers. The paper makes two main contributions to the literature. First, it adds to current knowledge about employees' wellbeing (inter-organizational work). Second, it expands the literature by exploring the combined management practices of both employees' wellbeing and organizational performance in distance work.

\section{Methods}

This paper uses a qualitative (Bryman, 2004; Crabtree and Miller, 1999; Yin, 2009) multiple case study approach (Stake, 2006; Yin, 2009) that was undertaken in 2015 in four different companies. Within the context of inter-organizational distance work (Cropper et al., 2008; Verburg et al., 2013), the aim of this pilot study was to explore distance management practices that ensured both employees' wellbeing and organizational performance. 


\subsection{Case companies and recruitment}

Recruiting the case companies followed several principles: 1) the companies should have inter-organizational arrangements with formal contracts (Cropper et al., 2008), 2) the customers control the working conditions in which the employees work, and 3 ) the employees have limited access to their own managers due to distance (time and geography). Companies with these characteristics were identified via the internet and the research team's network. This list of companies was then checked against the following inclusion criteria: type of business, type of distance work (inter-organizational work), and long work periods at the customer's location (Denmark or intemational). The companies were contacted via email and phone calls.

The recruitment process resulted in four case companies: a software development company, an engineering consultancy, a management consultancy, and an advanced manufacturing company selling additional services. The four companies represent different types of business, but all have experienced the emergence of networked organizational forms and they all engage in inter-organizational projects.

Table 1: information about cose companies

\begin{tabular}{|l|l|l|l|l|}
\hline & Company A & Company B & Company C & Company D \\
\hline Type & $\begin{array}{l}\text { Software } \\
\text { development }\end{array}$ & $\begin{array}{l}\text { Engineering } \\
\text { consultancy }\end{array}$ & $\begin{array}{l}\text { Management } \\
\text { consultancy }\end{array}$ & $\begin{array}{l}\text { Advanced } \\
\text { manufacturing }\end{array}$ \\
\hline No. of employees & 170 & 3100 & 350 & 2000 \\
\hline $\begin{array}{l}\text { No. of distance } \\
\text { employees (total) }\end{array}$ & 165 & N/A & 280 & N/A \\
\hline $\begin{array}{l}\text { No. of employees } \\
\text { the interviewed } \\
\text { manager is } \\
\text { managing }\end{array}$ & 165 & 30 & 38 & 70 \\
\hline $\begin{array}{l}\text { National or } \\
\text { international } \\
\text { distance work }\end{array}$ & National & National & International & International \\
\hline
\end{tabular}

\subsection{Data collection}

The researchers conducted 17 semi-structured interviews with the case companies (Kvale, 1996; Robson, 2002); these contained questions about distance management practices and distance work experiences, especially regarding employees' wellbeing and organizational performance.

The dataset from the four companies consists of one manager from each company together with up to four of their distance workers located at their customers' companies (see Table 2). All of the interviewees had experience with inter-organizational distance work as managers (with HR responsibility), project managers, or consultants/specialists. All of the employees worked for a minimum of two weeks at the customers' locations, and the majority had 
worked at these locations for several years. Their experiences with distance work and/or management varied from six months to 17 years, and the majority of the interviewees had been involved in several different projects with a variety of customers.

Table 2. Distribution of managers and employees

\begin{tabular}{|l|l|l|l|l|l|}
\hline $\begin{array}{l}\text { Organizational } \\
\text { position }\end{array}$ & $\begin{array}{l}\text { Company A: } \\
\text { no. of } \\
\text { participants }\end{array}$ & $\begin{array}{l}\text { Company B: } \\
\text { No. } \\
\text { participants }\end{array}$ & $\begin{array}{l}\text { Company C: } \\
\text { No. of } \\
\text { participants }\end{array}$ & $\begin{array}{l}\text { Company D: } \\
\text { No. of } \\
\text { participants }\end{array}$ & $\begin{array}{l}\text { Total no. of } \\
\text { participants }\end{array}$ \\
\hline Managerial & 1 & 1 & 1 & 1 & 4 \\
\hline Employee & 3 & 3 & 4 & 3 & 13 \\
\hline Total & 4 & 4 & 5 & 4 & 17 \\
\hline
\end{tabular}

The employees and managers were given different semi-structured interview guides. The employees' interview guide included two themes: 1) their subjective perceptions of the workrelated aspects of distance work (example: "What is the best thing about being a distance worker?"), and 2) their experiences with distance management (example: "How do you and your manager deal with the challenges you meet as a distance worker?").

The interview guide for the distance managers focused on their perspectives on distance work and the positive and negative aspects of being distance managers (examples: "How do you deal with the challenges and problems your employees meet in their work?" And: "What are your recommendations to other distance managers?"). The researchers conducted and recorded 12 telephone and five face-to-face interviews. Two researchers participated in each interview - one conducted the interview and the other took notes. Each interview lasted from 25-60 minutes.

\subsection{Data analysis}

The researchers coded the transcribed interviews using template analysis (King, 1998; Maznevski and Chudoba, 2000; Robson, 2002). In this study we focused on the experiences of the employees, the management practices and the expectations from the employees to their managers and had thereby already chosen the focus of our analysis, which made template analysis a relevant choice for the further data analysis.

In a template analysis the researchers usual defines a number of priori codes to guide the initial data analysis and in our study the three focus points thus served as the first three a priori codes.

The research question together with the questions asked in the interviews determined three a priori codes for the data analysis (Column 1, Table 3): 1) current distance management practices, 2) recommendations for distance management ensuring both wellbeing and performance, and 3) employees' distance work experiences. The researchers then applied the codes to the entire dataset, matching the codes with segments of data selected as representative of the code. In the second and third phases of the data analysis, the original codes were reanalysed - a number of additional codes and sub codes emerged that were then added to the matrix (Columns 2 and 3, Table 3). Table 2 presents the final template. The results section, in which the template guides the structure, includes an explanation of the different themes in Table 3, including their subthemes.

Table 3. Coding framework

\begin{tabular}{lll}
\hline First phase & Second phase & Third phase \\
\hline Current practice & Activities & Initiate contact on a regular basis \\
\hline & & Newsletters \\
\hline & Visits to the site \\
\hline
\end{tabular}




\begin{tabular}{|c|c|c|}
\hline & & Planning tasks \\
\hline & & Surveys \\
\hline & & Employee development talk \\
\hline & & Arrange social events and meetings \\
\hline & & Initiate talks with the customer \\
\hline & & $\begin{array}{l}\text { Phone call to employee after a couple of } \\
\text { weeks at the customer site }\end{array}$ \\
\hline & Capabilities & Being straightforward about performance \\
\hline & & Create and show trust \\
\hline & & Listen to the employee \\
\hline & & Give authority to the employee \\
\hline & & $\begin{array}{l}\text { Understand and acknowledge the } \\
\text { employee's given circumstances }\end{array}$ \\
\hline Recommendations & Activities & Visits to the site \\
\hline & & Initiate regular contact \\
\hline & & Be systematic about communication \\
\hline & & Ask concrete and difficult questions \\
\hline & & $\begin{array}{l}\text { Always allocate more than one employee } \\
\text { to a task }\end{array}$ \\
\hline & & $\begin{array}{l}\text { Make sure the job contains the potential } \\
\text { for development }\end{array}$ \\
\hline & & $\begin{array}{l}\text { Be ready to help should the employee } \\
\text { need it }\end{array}$ \\
\hline & Capabilities & Be a good listener \\
\hline & & $\begin{array}{l}\text { Be able to sense when things are about to } \\
\text { develop in the wrong direction }\end{array}$ \\
\hline & & Reach out to employees \\
\hline & & $\begin{array}{l}\text { Acknowledge that employees require } \\
\text { different management styles }\end{array}$ \\
\hline & & Create and show trust \\
\hline & & Show understanding and interest \\
\hline Experiences & Good & Responsibility \\
\hline & & Flexibility \\
\hline & & Difficult tasks \\
\hline & Bad & Loneliness \\
\hline & & Isolation \\
\hline & & Work conditions \\
\hline
\end{tabular}

\section{Theory}

In recent years, several theories have been proposed regarding distance work and management. Although the literature covers a wide variety of such theories in different contexts, the aim of this paper is to provide a clearer understanding of the practices of distance management and how to ensure employees' wellbeing and organizational performance across distances.

Hertel et al. (2005) stated that distance work, framed as distributed work, is a well-known phenomenon; however, now more than ever, technological development has made distance work management easier just as globalization has made it more attractive. The authors listed four distinctions of distributed work within the category of virtual work: 1) telework, where 
work is done out of the office; 2) virtual groups that combine teleworkers who share a manager; 3) virtual teams, where the virtual group works together to achieve a common goal; and 4) virtual communities, which go beyond the organizational structure and are often initiated by some of the employees (Hertel et al., 2005). The definition of virtual work that Hertel et al. (2005) provided is related to the definition of virtual organizations by Grabowski and Roberts (2016). They argued that virtual organizations are geographically distributed organizations whose members are bound by a long-term common interest or goal and who largely communicate and coordinate their work through information technology.

In contrast to viewing virtuality as the core of distance work, O'Leary and Cummings (2007) argued that dispersion in teams is a matter of spatial, temporal, and configurational dimensions. The spatial dimension refers to the geographic distance among team members. The temporal dimension is the time difference between team members. The configurational dimension covers the number of sites where the team members are located, isolation at sites, and the uneven distribution of team members across sites ( $O$ 'Leary and Cummings, 2007). According to Fisher and Fisher (2001), time, space, and/or culture constitute the distance between managers and employees. Their understanding of time and space is similar to O'Leary and Cummings' (2007) understanding, where the third dimension, cultural distance, can be within an organization (e.g., there are different cultures in two departments that work together or different national cultures). Where the mentioned understandings of virtual work evolves around geographical distribution, Fisher and Fisher's (2001) definition broadened this view by saying that distance does not need to be a product of geography - other things can have an effect as well. This paper builds upon the definition of distance work and management proposed by Fisher and Fisher (2001), but it includes understandings of virtual or dispersed organizations where there is relevant overlap.

In terms of management, there are several studies of management and leadership where the manager and employee work in different locations (Andressen et al., 2012; Huang et al., 2010; Joshi et al., 2009; Purvanova and Bono, 2009). In particular, transformational leadership, or parts of transformational leadership, impacts virtual teams (Andressen et al., 2012; Joshi et al., 2009), primarily influencing the team's or individual's effectiveness or productivity. Fisher and Fisher (2001) took an effectiveness approach to distance management, focusing on promoting a high level of employee performance. Hertel et al. (2005) argued that overall, delegating leadership principles, such as management by objectives and self-managed teams, is promising in relation to performance, but they call for studies of attributes of virtual team managers (Hertel et al., 2005). Taken together, studies of distance management and managers employ a performance perspective on leadership, while studies of the link between distance management and employees' wellbeing are rareknowledge about distance work and employees' wellbeing is altogether missing (Crawford et al., 2011).

Inter-organizational distance work typically takes the form of project work-similar to that of knowledge work (Brödner, 2009; Cropper et al., 2008). The ability to realize personal potential, gain self-fulfillment, and seek personal growth are some of the factors that motivate knowledge workers (Dunkin, 2003; Newell et al., 2002; Tampoe, 1993); these are motivation factors that are similar to fulfilling self-actualization needs (Maslow, 1965). Thus, it could be argued that the development of a knowledge society has fulfilled humans' basic needs.

Several studies point out that knowledge work offers a good job with a high level of influence, control, flexibility, and autonomy (Alvesson, 2004; Ipsen and Jensen, 2012; Newell, 2002; Sørensen and Holman, 2014a). Earlier studies, which are typically based on 
Karasek and Theorell's job decision latitude model (Karasek, 1979; Karasek and Theorell, 1990), find that such working conditions reflect a good psychosocial environment. However, other studies point out that wellbeing can be a problem for knowledge workers despite employee control and influence: knowledge work can cause frustration, work-related stress, and reduced performance (Ipsen et al., 2015; Leka et al., 2003; World Health Organization [WHO], 1999).

The increasing interest in distance work and management has led to different understandings of the phenomenon. However, in a wider context of project and knowledge work, the literature either focuses on employees' wellbeing or performance, and it does not specifically do so with regard to distance work. The literature shows that at the distance management activity level, more knowledge is needed regarding how managers ensure both wellbeing and performance. Thus, the literature provides the basis for the present study of how distance managers ensure both employee wellbeing and organizational performance within the domain of inter-organizational distance work.

\section{Results}

This section first presents findings about distance managers' current practices for ensuring both wellbeing and performance among employees. As part of these current practices, we include findings about the employees' experiences with distance work because they are somewhat related to current practices. Next, we present the interviewees' recommendations for distance managers. The findings are illustrated in Table 3.

\subsection{Current practices from the employees' perspective}

Employees' perceptions of distance managers' practices are split into two categories: activities and capabilities.

\subsubsection{Activities}

Activities relate to contact between the employees and the distance managers, information from the distance managers to the employees, planning, and feedback from the employees to the distance managers.

The activity 'contact' refers to maintaining a regular contact between the employee and the manager. The employees expect their managers to initiate contact regularly; they do not think it is their task as employees to do so. The contact between the employees and the distance managers both ensures that the managers know about the progress of the project and that they have the opportunity to ask about the employees' wellbeing. Another facet of contact is visits from the distance managers to the site. The interviewed employees stated that visits give the distance managers the chance to see whether they are doing okay from a wellbeing perspective.

Some of the employees also referenced the newsletters that their distance managers sent them as an important activity. In their view the newsletters had two main effects. First, the newsletters gave thema sense of belonging. This is important for the employees because they do not have physical proximity with their companies, but the newsletters provide a certain mental proximity. The second effect was in relation to knowledge sharing. Because the employees do not see their colleagues very often, the newsletter is a way for them to remain informed about who works where and which projects are in the pipeline. 
I'm not really involved in what happens in the development of the department ... I am one of the employees that creates profit for the department, which others can then use in the development of the department. (Employee, 4 years of experience)

Another practice the employees identified regarded planning: planning tasks in order to decrease the number of overlapping tasks for the employees, planning tasks so that the employees had an opportunity to develop professionally, and negotiations about project setup with the sales department.

Some of the employees worked at the customers' sites, which were physically located in the same area as the worksites. These employees sometimes worked at two customers' sites at the same time because their managers had asked them to do so. In situations where they worked at two customers' sites on two different projects, employees' workload increased at the same time on the two projects, which was difficult to handle. The employees who had encountered this situation reported good experiences in explaining to their distance managers that they needed to plan ahead in order to avoid two projects at once. The other aspect of planning was when employees needed their distance managers to allocate tasks that would challenge the employees professionally.

I also engage in dialogue with my manager and my project manager about some guidelines for my professional and personal development ... what I want to develop during the year ... We try to match expectations so that I am not simply assigned to a project that I have worked on eight times before and where there is no development. (Employee, 3 years of experience)

In the third aspect of planning, the employees appreciated that their distance managers put time and effort into negotiating with the sales department. Negotiation is important because the sales department writes the contracts with the clients, and in these contracts, it is crucial to make clear statements about requirements for working conditions.

The employees also identified a practice about feedback. There were different approaches to feedback from the distance managers to the employees, but most of the distance managers had a practice that involved some sort of feedback. In two of the case companies, the distance managers used surveys. One administered a survey at the beginning of the contract with the client, where both the employee and the client answered questions about the initiation of the project and reported whether they were satisfied with everything. The other used surveys once a month to gain knowledge about employees' wellbeing.

\subsubsection{Capabilities}

The distance managers' capabilities, from an employee perspective, were to be straightforward about performance, listen to the employees, give authority to the employees, and understand and acknowledge the circumstances in which the employees worked at the clients' sites.

The employees stated that they had good experiences with their distance managers being very straightforward about their performance. The explanation for this capability was that because the employees do not meet in person with their managers, they need very clear information about whether their managers are satisfied with their work.

He is very direct, and he tells you clearly if things are not okay ... he does not try to compromise; if things are not okay, he tells you. (Employee, 12 years of experience.) 
When the employees experience uncertainty about performance expectations, it is difficult for them to know how to address this. The employees stated that if their distance managers are straightforward, it is easier for them to be straightforward with the managers when they experience problems.

The employees also found listing to be an important capability of their distance managers. They elaborated that listening was about hearing what they said as well as what they did not say. The capability of listening can be time consuming for distance managers, but the time is well spent.

It is extremely important for the manager to listen, as sometimes an employee will call the manager to talk about a certain issue when it is actually something else that is bothering him ... then the employee needs a manager who will take the necessary time, listen, and says "yes" at the right time . . . because otherwise the employee can suddenly feel very much alone. (Employee, 12 years of experience)

Another capability the employees identified was to give the employees authority. The employees argued that when they work away from their distance managers, they often find themselves in situations where they need to make snap decisions; they cannot involve their managers every time this happens. In order to give the employees the authority to make decisions, the distance managers must accept that they cannot control everything. All of the employees said that one of the best things about doing distance work was the great deal of responsibility and autonomy they are given in their daily work. If the managers do not loosen their control, this can have negative effects on the employees.

You need to feel that you have some responsibility; you need to feel that you make a difference. [As manager] You need to be careful not to remove the basis for a decision from the one on the distance... then you will no longer feel that you make a difference. (Employee, 9 years of experience)

Another employee described how he believed that he had a good sense of when he should involve his manager and when he could make decisions himself:

It's about mutual trust. I have a fairly good idea about what decisions I can make in advance and inform my manager about them afterward . . . And I also know when I need to talk to him beforehand, as the decision may have consequences for the home office. (Employee, 10 years of experience)

The last capability the employees identified regards the distance managers showing understanding and acknowledging the employees' circumstances. In one case, where the employees work in remote areas around the world, the employees said that they were very happy that their distance manager had been a distance worker before, which they felt helped him be more aware of their circumstances. These employees experienced circumstances such as low levels of safety, lack of hot water, and limited Internet access. In the other cases, the clients offered worse working conditions to the distance workers than to their own employees. The employees' frustration with these circumstances decreased, when the manager acknowledged their situation.

One employee described a case where the circumstances were somewhat extreme: 
When you have not had warm water for three days and the phone does not always work ... you need to express your slight lack of satisfaction [said with a very ironic tone], and you call the home office. When your manager has had the same experiences, he will say, "Okay, I know it isn't easy" ... then you get sympathy from your manager, and that is very important - that the manager knows our reality. (Employee, 12 years of experience)

\subsection{Current practices from the distance managers' perspective}

\subsubsection{Activities}

The activities the distance managers mentioned included involvement in planning, different types of surveys with different purposes, team meetings, and contact with employees and customers.

The managers also identified activities in relation to planning, explaining that they are responsible for many planning tasks. Due to this, they felt it was important to include their employees in the planning when relevant because the employees had more hands-on experience and knew whether it was possible for them to do more than one project at a time or whether they needed two or three coworkers on the task.

Well, we have this task in a company that works in three shifts; when we do the task, we need to be there 24/7. So how do we do that? We need to be there over the weekend as well. It's difficult to plan more than a year in advance. When the time is approaching, we talk to the employees about how to do it. In this case, they had suggestions for the planning that were different from my initial plan, and we decided to use their plan... Therefore, we do a lot to involve our employees in the practical planning, as I think it is important that when employees are asked to do a task with a heavy workload, they are involved in the planning. (Distance manager, 6 years of experience as a distance manager)

One manager used monthly surveys to gain information about his employees' wellbeing. He used their answers to determine whether some of his employees needed to shift to another project because they were not thriving in their current assignment.

We have what we call a "pulse check," where every month we carry out a small employee satisfaction survey ... They answer five questions about, for example, whether they think they learned something on the project, whether they think the project will create value for the client, and whether they think the project was fun. We discuss the results in the project group every month. Once we could see that the satisfaction was decreasing on a very long project; the employees considered the tasks tedious because they had worked on the project for nine months. Then we discussed what to do about it. (Distance manager, 6 years of experience as a distance manager)

Another manager surveyed his employees at the start of each new project. The aim of these surveys was twofold: 1) he wanted to learn about the employees' experiences with the beginning of the project, and 2) he wanted to learn whether the clients were satisfied with the employees.

In relation to this activity, one manager had a rule of thumb to always call the client and ask firsthand whether he or she was satisfied with the project and the employees. The distance 
manager often only heard from the client if he or she was dissatisfied, and in order to be proactive, he initiated these calls because it was a way to nip dissatisfaction in the bud.

Some of the managers arranged meetings within their teams. Some meetings were social events, where the employees could talk to the colleagues they rarely saw. Information meetings about what was happening in the department were also organized. One manager arranged meetings with professional content; here, employees had the chance to develop professionally and also meet with their colleagues. One manager had department meetings every second month, and he always arranged for the department to eat together afterward because it gave the employees a chance to talk to their colleagues and share their experiences:

We arrange different things in continuation of the department meetings - we go out to eat or go see a play or something like that ... because when people know each other well, they work together better, they are more satisfied with their job, and it is also extremely important that we share experiences ... This has both a professional and a social aim; we share our experiences and we make it fun to go to work, knowing that there are colleagues who can provide support in difficult situations or when someone needs advice. (Distance manager, 8 years of experience as a distance manager)

Another activity the managers mentioned was creating newsletters. They considered newsletters to be an easy way to communicate messages to the entire department because physically gathering all of the employees was difficult. When the department did convene, they did not spend much time on the information included in the newsletters, which was considered to be a timesaving advantage.

\subsubsection{Capabilities}

The distance managers only mentioned one practice that falls in the category of capabilities: creating and showing trust. Not all of the distance managers mentioned building trust as something they did currently, but the ones who did were very clear about the importance of building a trusting relationship with all of their employees, in which trust went both ways:

There needs to be trust, I need it ... Employees must be autonomous - they must be able to make decisions when they are so far from the home office. It is useless if they need to call me during the night because they're having trouble in Indonesia. That's why they need to be autonomous. But they also need to know that when they make decisions, I will not be mad afterward. This demands trust - trust that I will believe they made the right decision, and the other way around, that they will know if they make a poor decision, I won't be furious at home. Trust is difficult; it's not something you buy. It takes a long time to develop. (Distance manager, 2 years of experience as a distance manager)

\subsection{Employees' and distance managers' recommendations}

The employees and the managers provided recommendations for distance managers regarding both activities and management capabilities. Some of the activities and capabilities mentioned are the same as those being part of current practice, whereas others are new.

\subsubsection{Activities}

The new activities include communication and planning. 
Communication is key to the employees. They were very clear that it is not only a matter of when to communicate and how often, but that it is a matter of which questions the distance managers ask. If they ask an open question such as "How are you doing?", it can be difficult for them to detect the wellbeing of the employees from their responses. The distance managers need to be more specific when asking questions, for instance, instead of asking "How are you doing?", they could ask "How is the apartment you live in?" (or other concrete questions), making it easier for the employees to answer specifically and honestly. Furthermore, the managers should not be afraid to ask difficult questions such as "What do you think about the people involved in the project?"

You test the water, you know, and hear how people are doing and ask concrete questions ... You prompt people to say more than when you say "How's it going?" and they answer "Okay," and then it is over. (Employee, 16 years of experience)

Some of the employees felt it would be a good idea for the distance managers to initiate contact with the employees on a regular basis. They said that some would probably think it was too much, but others would need to have contact often, and therefore, the managers should oblige.

The other new activity was in relation to planning. The employees wanted their managers to make a policy of always allocating more than one employee to each project. In this way, the managers could avoid creating feelings of isolation at the clients' sites.

Make sure ... that people are not alone on projects - that they always have someone to discuss things with and work with on the task they're doing for the client. I think you should stay away from sending people out alone if possible. Few employees enjoy being by themselves. (Employee, 10 years of experience)

The distance managers said that if they were to give advice to newly appointed distance managers, they would tell them to keep in close contact with all of their employees on a regular basis and be ready to help whenever the employees needed it. This regular and close contact is particularly important for the distance managers because some of the employees do not contact their distance managers regularly. They risk being forgotten if the distance managers do not prioritize contacting their employees. They also said they would advise new managers to do everything they can when an employee says he or she needs help. The distance managers stressed how important this is because normally, employees are very autonomous and independent, so when they say they need help, there is an actual need for help.

I think it's important to be able to help immediately if there is a problem. It is an uncomfortable feeling to be out at the client when there's a fire under your feet and you're alone. (Distance manager, 6 years of experience as a distance manager)

\subsubsection{Capabilities}

The new capabilities the employees mentioned are that distance managers should acknowledge that employees require different management styles, that the distance managers should be attentive when talking to the employees, and that they should reach out to the employees. 
The capability regarding management styles relates to the fact that distance managers often oversee both new and experienced employees from different backgrounds; the employees therefore have different opinions about what they need from a manager.

He needs to be aware of who he is dealing with ... because there are many different needs depending on whether the employee has experience; some people are just more autonomous than others (Employee, 3 years of experience)

The employees felt that the ideal distance manager would be attentive and reach out to the employees. In order for distance managers to develop a relationship with their employees, as they rarely meet, it is important that they are attentive and reach out to the employees on a regular basis.

Then you need to remember to listen to him, so it is important to call him and hear about how things are going. Make an effort to show interest in him and what he is doing. (Employee, 9 years of experience)

The distance managers pointed out two capabilities: creating trust and being able to sense if things are about to develop in the wrong direction.

All of the interviewed managers emphasized the importance of creating trust, also mentioned as a capability in the current practices, between distance managers and employees. The distance managers all acknowledged that trust is difficult, and it takes time to establish trusting relationships:

It is important to build relationships with all your employees, even though this can be difficult ... You must figure out how to create a trusting relationship between yourself and your employees; that is important. (Distance manager, 8 years of experience as a distance manager)

The last capability the distance managers mentioned is being able to sense when things are about to develop in the wrong direction. Because communication between the employees and the distance managers takes the form of emails and phone calls, managers must be adept at reading between the lines and reacting quickly when things are about to develop in the wrong direction:

We only do follow up when ... you could say that if we feel something is wrong, and nothing has been said, then we follow up. (Distance manager, 18 years of experience as a distance manager)

\section{Discussion}

The aim of our study was twofold. First, we explored the wellbeing of employees in interorganizational distance work. Second, we examined current distance management practices meant to ensure both employees' wellbeing and organizational performance. The exploration of employees' wellbeing revealed that employees are very enthusiastic about their workthey like that it is autonomous and flexible. The negative side of distance work is that some of the employees feel isolated and lonely. The examination of distance management practices illustrated that distance managers do many things to ensure their employees' wellbeing and performance. In the data analysis, we split the overall theme into two subthemes: activities and capabilities. 


\subsection{Employees' wellbeing in distance work}

The increasing interest in distance work and management has led to different understandings of the phenomenon. We know very little about the wellbeing of employees who work at clients' or customers' offices (inter-organizational work) for a long period of time. One of this study's goals was to explore how employees experience their work at customers' sites.

The findings show that employees experience distance work positively. The job is flexible with a high level of autonomy and the potential for personal growth. Employees' specialist skills are both challenged and applied, which is stimulating for the employees. The results generally agree with those obtained in previous wellbeing studies-they show potential for the fulfillment of self-actualization needs (Brödner, 2009; Maslow, 1965). As in previous studies of knowledge workers' wellbeing (Ipsen and Jensen, 2012; Sørensen and Holman, 2014b), we also saw frustrating experiences like loneliness and isolation in the case of distance work. A study on teleworkers' wellbeing also found frustration and isolation as a negative part of being teleworkers (Whittle and Mueller, 2009).

Furthermore, our results showed that unpleasant reception and treatment by the customers, poor physical working conditions, too high performance expectations from the first day on the job, and delayed response time from their distance managers caused frustration and affected employees' wellbeing. In more extreme cases, the employees named a lack of hot water for several days, limited online access, power crashes, and local safety issues as factors affecting their wellbeing. Consequently, this study concludes that physical and social working conditions at the work sites, both nationally and internationally, directly affect the employees' wellbeing and thus their performance. This study stresses the importance of addressing employees' basic needs, like physiological needs, safety, and belongingness, in order to ensure motivation. The reason for this is that this study offers new knowledge that employees engaged in inter-organizational distance work are at risk of inadequate working conditions where their basic needs are not met. This adds to our current knowledge about motivation of knowledge workers.

So despite potential for the fulfillment of self-actualization needs in distance work, this study shows that good working conditions that satisfy physiological and safety needs, be it hot water, on-site safety, or the quality of the office facilities, are also needed to ensure employees' wellbeing (inter-organizational work), enabling high performance. To ensure fulfillment of self-actualization and consequently employees' wellbeing and performance, this study suggests that distance managers should be aware of the customers' working conditions and their capability to fulfill their distance employees' basic and self-actualization needs.

\subsection{Distance management practices}

We identified a number of practices that distance managers engage in as well as some that the employees and distance managers recommend other distance managers adopt. The employees identified many different practices that their distance managers engage in. This study interprets the many identified practices as the employees shows interest in what their managers do.

Both the employees and the distance managers mentioned trust as crucial to their relationships with each other. Trust was often mentioned in relation to the autonomy of the employees, showing that trust and worker autonomy are interlinked. Crawford et al. (2011) 
highlighted the importance of trust and worker autonomy in distance work, stating that it requires managers to take a different approach to their management style. Trust in interorganizational distance work relates very much to employees' autonomy and decisionmaking authority. Worker autonomy was somewhat required by the managers. This type of employee responsibility requires trust that goes from the employee to the manager and vice versa. Management principles about delegating tasks and responsibilities are more suitable for distance managers than are Tayloristic principles (Hertel et al., 2005). The review by Hertel et al. (2005) considered management principles from a performance perspective. In contrast, the present study combines wellbeing and a performance perspective. Management style is a key factor in the interplay between employees' wellbeing and performance (Westgaard and Winkel, 2011), and a management style that uses delegation principles and therefore emphasizes autonomy positively affects employees' wellbeing (Konradt et al., 2003).

Some of the interviewed distance managers arranged different types of events for their employees in order to develop the team and facilitate knowledge sharing between the employees. The managers were very clear that they had this goal in mind when implementing this particular activity. Knowledge sharing facilitation is a topic within research in knowledge-intensive organisations, where it is recognized that the manager needs to do the facilitation (Millar et al., 2016). The discussion is also present within distance work, where Burtha and Connaughton (2004) argues that face-to-face events build "environments," which are important for organizations. While Burtha and Connaughton (2004) found these to be relevant for intra-organizational distance work, our results show that events are important in inter-organizational distance work as well.

The managers used different activities to either investigate or support employees' wellbeing and performance; however, these activities do not ensure both employees' wellbeing and organizational performance. When the distance managers use capabilities such as showing trust or listening, the activities evolve from a mechanistic tool to a practice that ensures both employees' wellbeing and organizational performance. This comes to show in our findings where the employees in their descriptions of the communication activity uses similar expressions as when describing the capability to be attentive and to reach out. In order to successfully engage in the communication activity the manager needs to develop the capability to reach out and to be attentive.

The implication of this finding is that distance managers, needs to be aware that activities alone do not ensure both wellbeing and performance. They also need to consider their capabilities. Our findings show that the activities and capabilities are interdependent.

Therefore we suggest that distance managers consider: 1) how they can use their capabilities, and 2) in which activities they can apply their capabilities to ensure both well-being and performance

This study indicate that managers who are able to both consider activities and capabilities as part of their management focus on both wellbeing and organizational performance.

Our findings also show that wellbeing and organizational performance are interdependent, which becomes clear when the physical and social working conditions are poor, and directly affects the performance. When acknowledging the interdependency between wellbeing and organizational performance the distance manager we see the managers respond accordingly with activities and capabilities. 
Previous studies have not been concerned with the interdependency between wellbeing and performance (Westgaard and Winkel, 2011), however there is an increased awareness of the need for new knowledge regarding balancing wellbeing and organizational performance (Edwards and Jensen, 2014; Hvid et al., 2011) and thus sustainable management (Ipsen and Edwards, 2016).

In the template analysis, the distance management practices covered both activities and capabilities. We did not expect to find capabilities mentioned as a practice. This finding indicates that employees highly value intangible practices (capabilities) such as listening, understanding, and acknowledgement.

\subsection{Limitations}

The main limitation of this study is that this is a small research study with only four cases. However, the purpose of the study was not to establish frequencies but a range of responses to gain insight into management practices in relation to employee wellbeing and performance in inter-organizational distance work. Collecting data from four cases, i.e. 17 interviews, enabled us to gather enough data to identify the desired insights at this early stage of the field.

A second limitation is, that the study only was conducted in Denmark. The results and conclusions may therefore only apply to the Danish context. We therefore suggest that further studies of inter-organizational distance work is carried out in other countries to add to our knowledge about wellbeing and performance in inter-organizational work.

A third limitation is the lack of interviews with managers from the customer. These managers could contribute with their perceptions of the responsibility of ensuring both wellbeing and performance of the distance employee. It was not included in our study, but it would be a recommendation for further studies.

\subsection{Conclusion}

The present study of inter-organizational distance work shows that distance employees experience both positive and negative wellbeing. It also shows that inter-organizational distance management focusing on both employees' wellbeing and organizational performance is characterized by activities that focus on dialogue and feedback as well as strong managerial perceptual skills. This supports the literature suggesting that sustainable management deals with both wellbeing and performance simultaneously by using dialogue.

The distance management activities primarily concern conversations (dialogue) and target the employees, the project managers, and the customers prior and during their stay at the customers' sites. The activities are systematically conducted within an allocated amount of time, with fixed content, and with fixed frequency; this facilitates continuous follow up to ensure a sense of proximity despite the distance. Managers also apply different management tools (surveys and overviews) to collect data to support their conversations. In this way, the study adds to the literature on sustainable management practices.

The conversations focus on both wellbeing and performance, including the actual working conditions at the customers' sites. Due to the distance, the conversations require good managerial perceptual skills characterized by the ability to hear what is (actually) being said (paying attention) and establishing trust. Finally, this study shows that sustainable managers are able to reflect upon and acknowledge their own roles in the distance workers' wellbeing and performance. 
Acknowledgements

We would like to acknowledge I-BAR for the opportunity to conduct this study.

\section{References}

Alvesson, M., 2004. Knowledge Work and Knowledge-Intensive Firms. Oxford University Press, New York.

Andressen, P., Konradt, U., Neck, C.P., 2012. The Relation Between Self-Leadership and Transformational Leadership: Competing Models and the Moderating Role of Virtuality. J. Leadersh. Organ. Stud. 19, 68-82. doi:10.1177/1548051811425047

Bell, B.S., Kozlowski, S.W.J., 2002. A Typology of Virtual Teams: Implications for Effective Leadership. Gr. Organ. Manag. 27, 14-49.

Bryman, A., 2004. Social Research Methods. Oxford University Press.

Brödner, P., 2009. Sustainability in knowledge-based companies, in: Docherty, P., Kira, M., Shani, A.B. (Eds.), Creating Sustainable Work Systems - Developing Social Sustainability. Routledge, Hong Kong, pp. 53-69.

Burtha, M., Connaughton, S.L., 2004. Learning the secrets of long-distance leadership - Eight principles to cultivate effective virtual teams. Knowl. Manag. Rev. 7, 24-27.

Crabtree, B., Miller, W., 1999. Doing Qualitative Research. London: Sage.

Crawford, J.O., Maccalman, L., Jackson, C.A., 2011. The health and well-being of remote and mobile workers. Occup. Med. (Chic. Ill). 61, 385-394. doi:10.1093/occmed/kqr071

Cropper, S., Huxham, C., Ebers, M., Ring, P.S., 2008. The Oxford Handbook of InterOrganizational Relations, Ist ed. Oxford University Press. doi: 10.1093/oxfordhb/9780199282944.001.0001

Dunkin, R., 2003. Motivating Knowledge Workers. High. Educ. Manag. Policy 15, 41-49. doi:10.1787/hemp-v15-art22-en

Edwards, K., Jensen, P.L., 2014. Design of systems for productivity and well being. Appl. Ergon. 45, 26-32. doi:10.1016/j.apergo.2013.03.022

European Agency for Safety and Health at Work, 2013. Wwllbeing at work: Creating a positive work environment - Exploring the concept of WAW within the EU. European Union, Luxembourg. doi:10.2802/52064

Fisher, K., Fisher, M.D., 2001. The Distance Manager. A Hands-On Guide to Managing OffSite Employees and Virtual Teams. McGraw-Hill.

Grabowski, M., Roberts, K.H., 2016. Reliability seeking virtual organizations: Challenges for high reliability organizations and resilience engineering. Saf. Sci. doi:10.1016/j.ssci.2016.02.016

Hertel, G., Geister, S., Konradt, U., 2005. Managing virtual teams: A review of current empirical research. Hum. Resour. Manag. Rev. 15, 69-95. doi:10.1016/j.hrmr.2005.01.002

Hinds, P., Kiesler, S., 2002. Distributed Work, Distributed Work. doi:10.2307/3094928

Huang, R., Kahai, S., Jestice, R, 2010. The contingent effects of leadership on team collaboration in virtual teams. Comput. Human Behav. 26, 1098-1110. doi:10.1016/j.chb.2010.03.014

Hvid, H., Bergholm, T., Gonäs, L., Juul, I., Kamp, A., Karlsson, J., Kasvio, A., Klemsdal, L., Salomon, R., Skorstad, E., 2011. Nordic Working Life Research - Continuity and Renewal. Nord. J. Work. Life Stud. 1, 3-21.

Ipsen, C., Edwards, K., 2016. Sustainable Management: Balancing Organizational Performance and Employee Well- being, in: Teoh, K., Dediu, V., Saade, N.J., Hassard, J. (Eds.), 12th EAOHP Conference : Occupational Health Psychology in Times of Change: Society and the Workplace. European Academy of Occupational Health 
Psychology, Athens, Greece, pp. 189-190.

Ipsen, C., Gish, L., Poulsen, S., 2015. Organizational-level interventions in small and medium-sized enterprises: Enabling and inhibiting factors in the PoWRS program. Saf. Sci. 71, 264-274. doi:10.1016/j.ssci.2014.07.017

Ipsen, C., Jensen, P.L., 2012. Organizational options for preventing work-related stress in knowledge work. Int. J. Ind. Ergon. 42, 325-334. doi:10.1016/j.ergon.2012.02.006

Joshi, A., Lazarova, M.B., Liao, H., 2009. Getting Everyone on Board: The Role of Inspirational Leadership in Geographically Dispersed Teams. Organ. Sci. 20, 240-252. doi: $10.1287 /$ Orsc. 1080.0383

Karasek, R., 1979. Job Demands, Job Decision Latitude, and Mental Strain: Implications for Job Redesign. Adminstrative Sci. Q. 24, 285-308.

Karasek, R., Theorell, T., 1990. The Psychosocial Work Environment, in: Healthy Work. Stress, Productivity and the Reconstruction of Working Life. Basic Books, Inc, New York, pp. 3I-83.

King, N., 1998. Template analysis, in: Casell, C. (Ed.), Qualitative Methods and Analysis in Organizational Research. A Practical Guide. SAGE Publications, London, pp. 118-134.

Konradt, U., Hertel, G., Schmook, R., 2003. Quality of management by objectives, taskrelated stressors, and non-task-related stressors as predictors of stress and job satisfaction among teleworkers. Eur. J. Work Organ. Psychol. 12, 61-79. doi: $10.1080 / 13594320344000020$

Kvale, S., 1996. Interviews: An introduction to qualitative research interviewing. Sage Publications.

Leka, S., Griffiths, A., Cox, T., 2003. Work Organisation \& Stress, Protecting Workers' Health Series. WHO, Switzerland.

Maslow, A., 1965. Self-actualization and beyond. Conf. Train. Couns. Adults 1-27.

Maznevski, M.L., Chudoba, K.M., 2000. Bridging Space Over Time: Global Virtual Team Dynamics and Effectiveness. Organ. Sci. 11,473-492. doi:10.1287/orsc.11.5.473.15200

Millar, C.C.J.M., Chen, S., Waller, L., 2016. Leadership, knowledge and people in knowledge-intensive organisations: implications for HRM theory and practice. Int. J. Hum. Resour. Manag. 5192, 1-15. doi:10.1080/09585192.2016.1244919

Neely, A., Gregory, M., Platts, K., 2005. Performance measurement system design - A literature review and research agenda. Int. J. Oper. Prod. Manag. 25, 1228-1263. doi:10.1108/01443570510633639

Newell, S., 2002. Creating the Healthy Organization. Well-being, diversity \& ethics at work, Psychology at Work. Thomson, Cornwall.

Newell, S., Robertson, M., Scarbrough, H., Swan, J., 2002. Managing Knowledge Work. Palgrave.

O'Leary, M.B., Cummings, J.N., 2007. The spatial, temporal, and configurational characteristics of geographic dispersion in teams. MIS Q. 31, 433-452.

Purvanova, R.K., Bono, J.E., 2009. Transformational leadership in context: Face-to-face and virtual teams. Leadersh. Q. 20, 343-357. doi:10.1016/j.leaqua.2009.03.004

Robson, C., 2002. Real world research : a resource for social scientists and practitionerresearchers. Blackwell Publishers, Oxford.

Stake, R.E., 2006. Multiple Case Study Analysis, 1st ed. The Guildford Press.

Sørensen, O.H., Holman, D., 2014a. A participative intervention to improve employee wellbeing in knowledge work jobs: A mixed-methods evaluation study. Work Stress 28, 67 86. doi:10.1080/02678373.2013.876124

Sørensen, O.H., Holman, D., 2014b. A participative intervention to improve employee wellbeing in knowledge work jobs: A mixed methods evaluation study. Work Stress An Int. J. Work. Heal. Organ. 28, 67-86. doi:10.1080/02678373.2013.876124 
Tampoe, M., 1993. Motivating knowledge workers-The challenge for the 1990s. Long Range Plann. 26, 49-55.

Verburg, R.M., Bosch-Sijtsema, P., Vartiainen, M., 2013. Getting it done: Critical success factors for project managers in virtual work settings. Int. J. Proj. Manag. 31, 68-79. doi:10.1016/j.ijproman.2012.04.005

Westgaard, R.H., Winkel, J., 2011. Occupational musculoskeletal and mental health: Significance of rationalization and opportunities to create sustainable production systems - A systematic review. Appl. Ergon. 42, 261-96. doi:10.1016/j.apergo.2010.07.002

Whittle, A., Mueller, F., 2009. "I could be dead for two weeks and my boss would never know": Telework and the politics of representation. New Technol. Work Employ. 24, 131-143. doi: $10.1111 / \mathrm{j} .1468-005 \times .2009 .00224 . x$

WHO, 1999. The burden of occupational illness.

Yin, R.K., 2009. Case Study Research: Design and Methods, Essential guide to qualitative methods in organizational research. doi:10.1097/FCH.0b013e31822dda9e 